\title{
35. Promoting cooperation for transboundary water security: The experience of the UNESCO Chair/INWEB
}

\author{
Jacques Ganoulis \\ Director of the UNESCO Chair/INWEB (International Network \\ of Water/Environment Centres for the Balkans), Aristotle \\ University of Thessaloniki, Greece
}

Katie Quartano

UNESCO Chair/INWEB, Aristotle University of Thessaloniki, Greece

Charalampos Skoulikaris

Secretary General of the UNESCO Chair/INWEB, Aristotle University of Thessaloniki, Greece

The UNESCO Chair/INWEB (International Network of Water/Environment Centres for the Balkans) at the Aristotle University of Thessaloniki (AUTh), Greece, was established in 2003 as part of the UNITWIN/UNESCO Chairs program. It links INWEB, a water resources management network of academic and non-academic groups in south eastern Europe (SEE, or the Balkans) that has been active since 1999, with the UNESCO Chair on sustainable management of transboundary waters and conflict resolution.

The UNESCO Chair/INWEB focuses on two main activities:

- promoting and carrying out innovative research and educational programmes, and

- contributing to bridging the gap between academic research and practical implementation of new knowledge in the field.

Being part of the extended UNESCO organisation means that INWEB seeks to promote cooperation, capacity-building and access to new knowledge in the Balkan countries and developing regions outside Europe. 


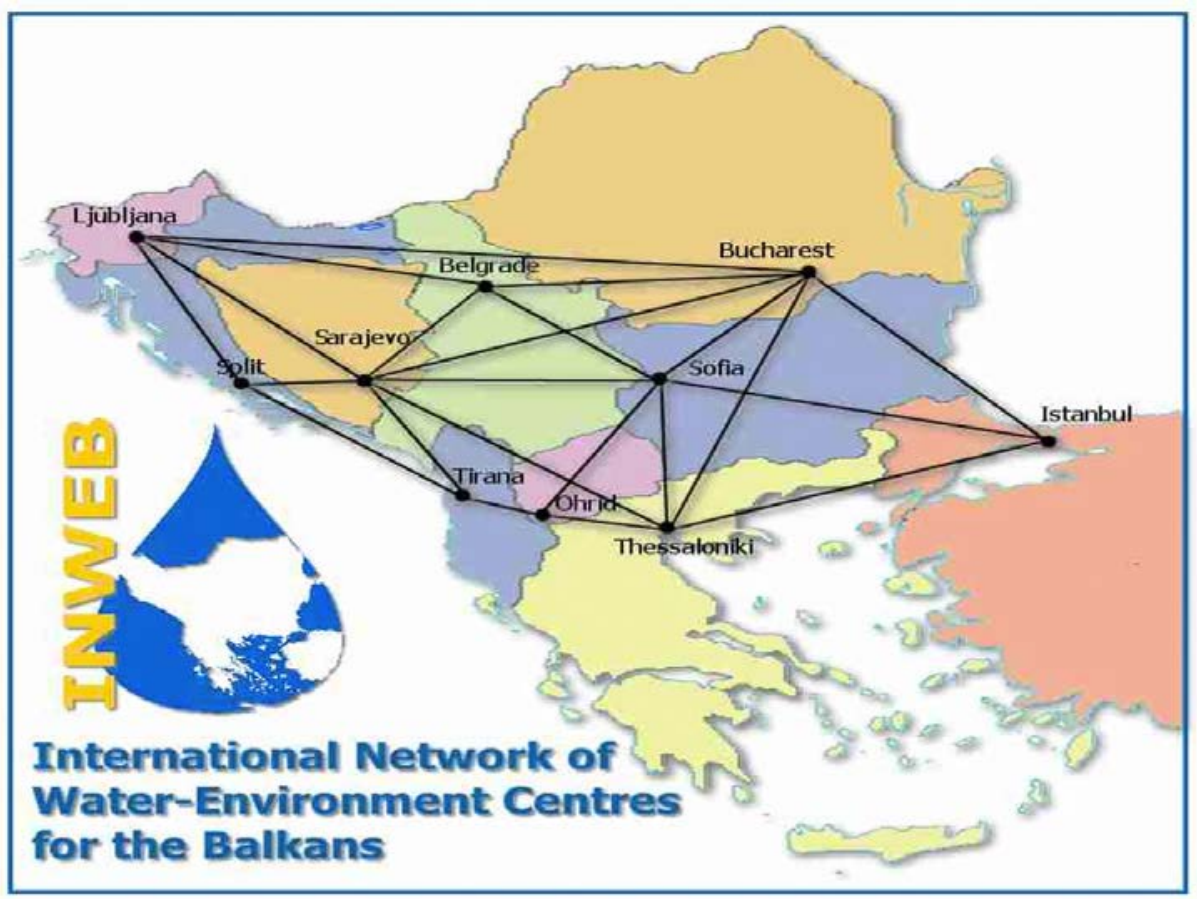

\section{Figure 1: The UNESCO Chair/INWEB in SEE - the Balkans}

Source: Authors' research.

In this region of Europe, water cooperation among countries is vital because many surface and groundwater resources are shared by two or more countries. Taking both the Sub-Danubian transboundary river and lake basins and the internationally shared aquifers into account, more than 80 per cent of the water resources in this region are transboundary (INWEB 2008).

In the interests of mutually beneficial development it is necessary to develop shared plans for the protection and management of transboundary water resources to safeguard them against pollution and floods, and also to jointly plan the construction of major infrastructure.

International cooperation at the basin level in the Balkans continues to be fragile. The problems of minority groups, perceptions of injustice and nationalistic tendencies continue to pose a threat to the stability and social and economic development of the region. INWEB provides a framework within which relationships between scientists from all ten Balkan countries can be developed and reinforced in a spirit of rebuilding scientific cooperation across SEE. With this in mind, INWEB promotes cooperation by using water as a tool for peace. Our belief is that regional concerns over water issues can unite rather than 
divide, and that countries can work together to improve water quality and ensure long-term water security. It is clear that successful regional cooperation begins with all participants understanding the importance of sharing information and knowledge at the appropriate time.

\section{INWEB's regional inventories of transboundary waters}

Monitoring programs in the Balkans were in many cases disrupted, or even abandoned, during regional conflicts. Data is therefore difficult to obtain and may be incomplete. The new institutional structures within the multitude of small international river basins created by the collapse of the former Yugoslavia cannot in many cases provide consistent and complete historical information. There is an urgent need for improved development and sharing of both water quantity and quality data in transboundary river basins throughout the area. INWEB is working to address this need, as can be seen from the identification in 2008 of 17 Sub-Danubian transboundary river and lake basins in the SEE (Figure 2).

Groundwater exploitation in SEE has increased dramatically during recent decades. Over-exploited aquifers are consequently a major concern in most countries. Many groundwater resources are at risk of being exhausted to meet the rising demands of irrigated agriculture, tourism and industry. The pressures on groundwater resources are highest in the summer period, when natural supply is minimal and water demand is at a maximum for irrigation and tourism. Groundwater scarcity is often accompanied by poor water quality, particularly in coastal aquifers where water is often highly saline and unusable. In addition to a general trend towards over-extraction, contamination in recharge areas and mismanagement of irrigation practices has led to a general deterioration in groundwater quality in many parts of the Mediterranean region.

Transboundary aquifer systems are important sources of fresh water in many regions of the world, particularly under the arid-and semi-arid climatic conditions which prevail in the Mediterranean region. With growing groundwater scarcity and quality deterioration, the demands on these shared aquifers to meet growing regional water demand are only likely to increase. In this situation, a fundamental task for joint management is the production and sharing of reliable scientific knowledge and information to mitigate potential conflicts between neighbouring countries. Furthermore, cooperative arrangements to jointly develop, manage and protect shared aquifers will become a necessity, not only to avoid conflict, but also to optimise utilisation and to achieve water security. 


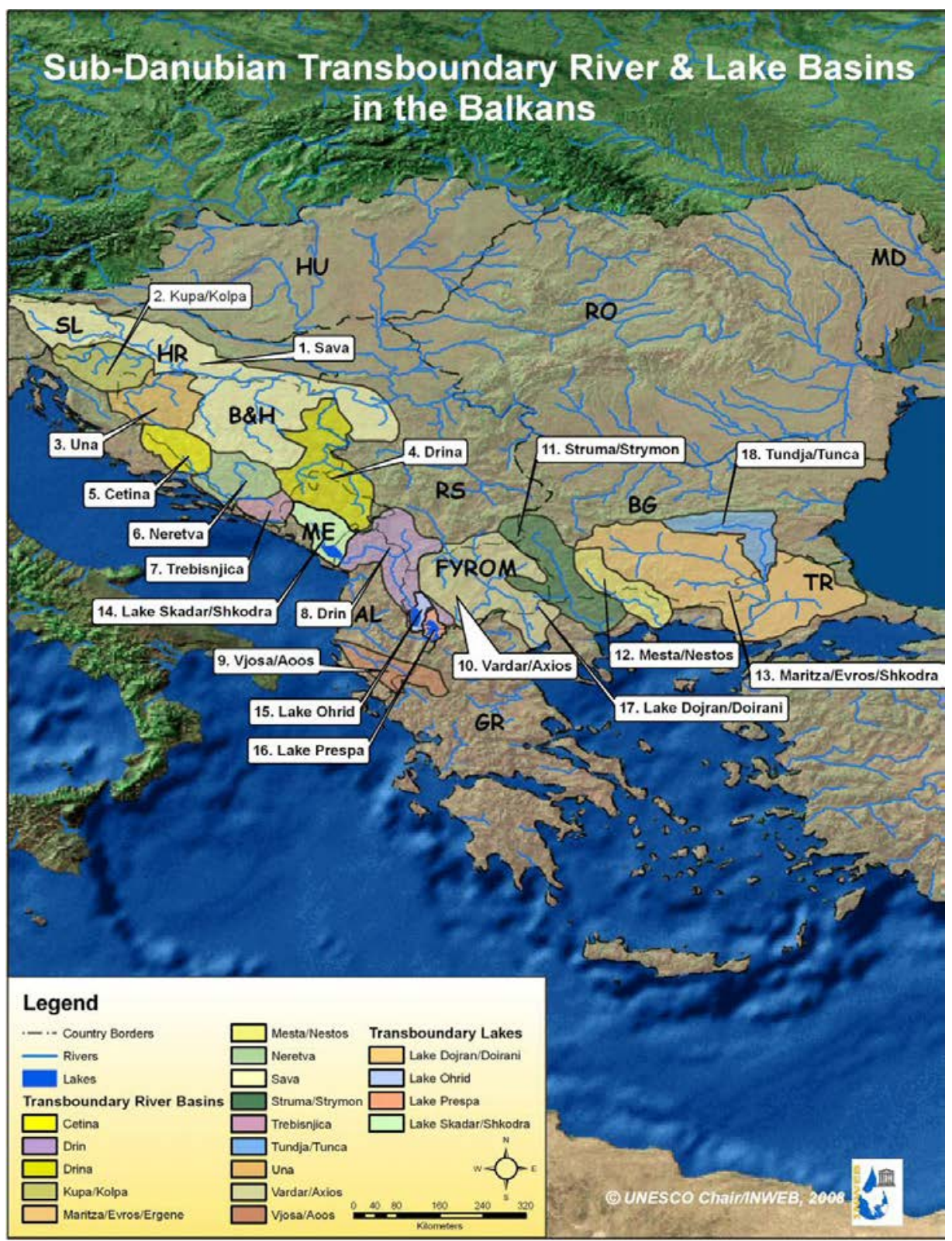

Figure 2: Sub-Danubian transboundary river and lake basins in SEE

Source: INWEB 2008. 


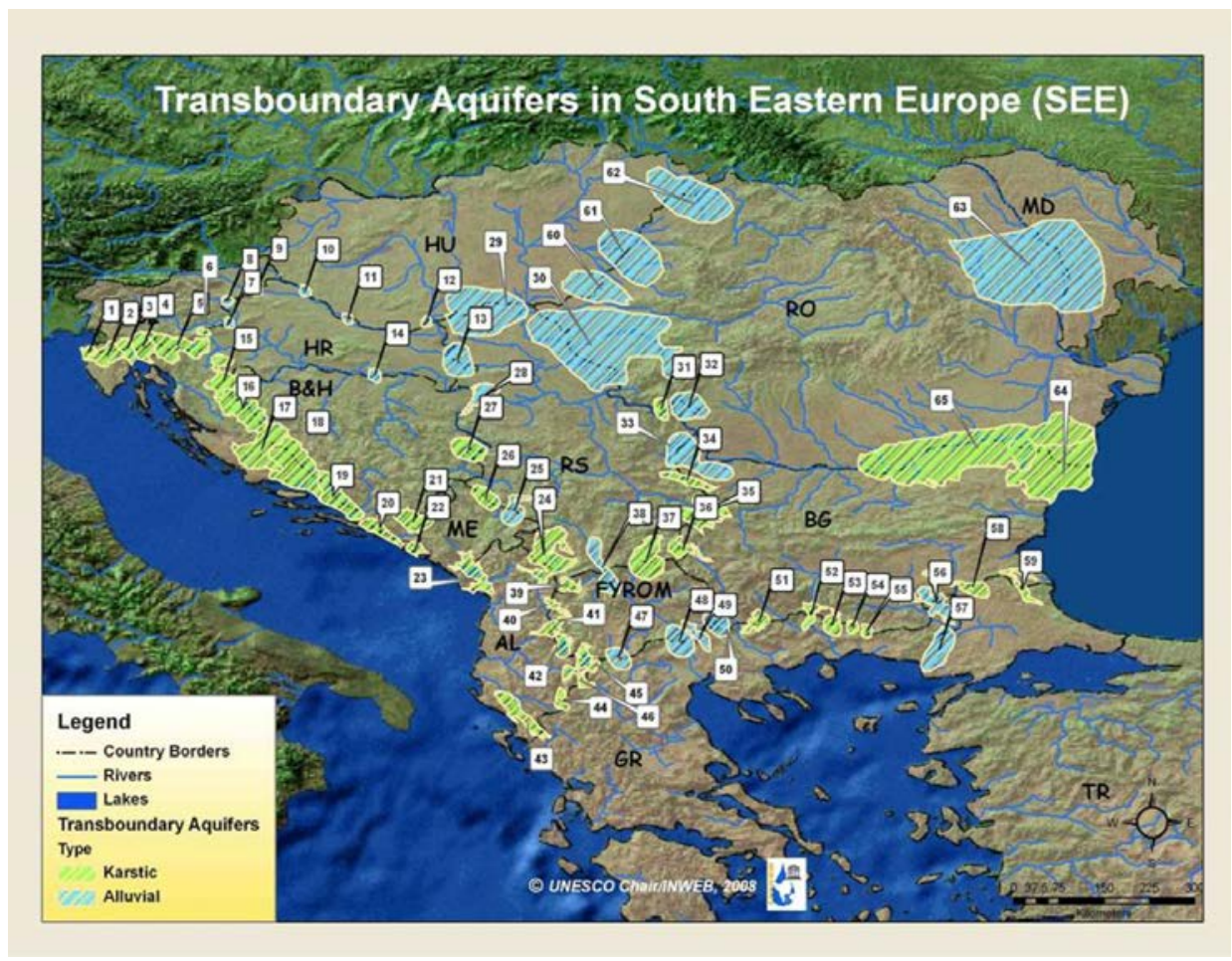

Figure 3: Overview map of transboundary aquifers in the SEE region

Source: Authors' research.

In order to facilitate an integrated approach to transboundary groundwaterresources management in the Balkans, INWEB adopted the UNESCO/ISARM (International Shared Aquifer Resources Management) initiative. This was launched in June 2000 at the 14th Session of the Intergovernmental Council of UNESCO-IHP (International Hydrological Programme) and is an intergovernmental project involving all national IHP Committees.

A number of UNESCO-ISARM activities have taken place in the Mediterranean region, particularly in SEE. In this region the UNESCO Chair/INWEB has worked with UNESCO/IHP, the Economic Commission for Europe (ECE), the Economic and Social Commission of Western Asia (ESCWA), and the Economic Commission of Africa (ECA) to investigate shared aquifer resources using a two-step methodological approach: (1) collate available data from a wide range of sources and develop an inventory of the transboundary aquifers across the entire region, and (2) make an interactive online meta-database available to all stakeholders using Google Earth technology. 
Some transboundary aquifers in the region had previously been identified and noted in earlier UNECE and INWEB inventories. The region has, however, seen major political change in the last two decades and many aquifers that were located within a single country are now shared between new countries. For example, while the previous UNECE inventory recorded 23 regional transboundary aquifers and the draft INWEB reported 47, this latest assessment identified 65. The locations of these aquifers are shown in Figure 3.

The database of transboundary aquifer resources in SEE is available on INWEB's web platform (http://www.inweb.gr). Two main types of aquifers are distinguished:

1. Sedimentary basins with shallow unconfined aquifers and deep confined layered aquifers, namely alluvial aquifers. Unconfined aquifers are found in river channels or in floodplains and are usually recharged by direct infiltration of rainfall or streamflow; nevertheless due to their shallow nature, they are subjected to contamination and pollution risks. On the other hand, the water volume stocked in confined aquifers is under pressure, since an overlaying impermeable layer deteriorates the quality of water seeping into or out of the aquifer. The replenishment of these aquifers occurs only in areas where the porosity of the confining layer allows water infiltration, usually at some considerable distance away from the aquifer. The recharge procedure is a long-term process and groundwater in these aquifers dates back centuries.

2. Karstic carbonate aquifers. This type of aquifer is found in areas where chemically soluble rock, such as limestone or dolomite, is dominant. This is due to the fact that flowing water containing carbon dioxide dissolves these rocks. For the countries along the Adriatic coast, the karstic aquifer complex known as the Dinaric karst (estimated at 110,500 square kilometres $\left(\mathrm{km}^{2}\right)$ ), is the main source of water supply. More than 73 per cent of the national territories of Croatia, Bosnia and Herzegovina, Montenegro and Albania lie over this significant aquifer complex. These aquifers are vulnerable to contamination since rock porosity, together with swallow holes, facilitate the diffuse or point infiltration of contaminants of pollutants.

\section{Integrated management of transboundary waters}

Different models for collaborative activities related to transboundary water resources management (TWRM) have been proposed globally (UN World Water Development Report (WWDR) 2006, 2009), and for the SEE region in particular 
(Ganoulis et al. 1996, 2000, 2006, 2011). The approaches of such models differ according to the particular associated scientific discipline or professional community.

On the one hand, engineers, hydrologists, hydrogeologists and environmental professionals, emphasise the physical and ecological assessment and modelling of transboundary hydro-systems in terms of:

- delineating their natural borders; i.e., hydrologic basins for transboundary rivers and lakes, and hydrogeological boundaries for groundwater aquifers

- analysing relationships between physical and ecological variables, such as precipitation, groundwater recharge, river flow, pollutant inputs, lake water quality, and ecological biodiversity, and

- suggesting constructional projects, such as dams, diversion channels and irrigation networks, or non-structural measures, such as demand management, ratification of EU legislation, developing agreements and implementing guidelines.

On the other hand, lawyers and social scientists (i.e., geographers, economists and sociologists) emphasise human factors that can be complex and difficult to analyse and predict, such as institutional cooperation, stakeholder participation and negotiation strategies. The main challenge here is whether different national administrations will implement international rules at the domestic level and, at the same time, coordinate their activities with their neighbours through bilateral or regional cooperation agreements. One way to address this challenge is to raise public and stakeholder awareness of and engagement with participatory processes involving national institutions, academic partners and international organisations.

In reality, all the above issues and approaches coexist and are inter-related. In order to achieve effective TWRM these models, whether descriptive or prescriptive, need to merge. Ganoulis et al. (2011) present two main strategies for achieving such integration: (a) through effective capacity building and training in TWRM, and (b) by producing and analysing a general framework of conflict resolution based on how riparian countries may share benefits and risks.

The UNESCO Chair/INWEB has chosen the Mesta/Nestos Basin as a case study of integrated TWRM in SEE. The river rises in the Rila and Pirin mountains in southern Bulgaria and flows some $230 \mathrm{~km}$ through Bulgarian and Greek territory before emptying into the North Aegean Sea (Fig. 4). About $126 \mathrm{~km}$ of the river flows through Bulgaria and about $130 \mathrm{~km}$ through Greece, with a total catchment area of $5613 \mathrm{~km}^{2}$ (2770 km² in Bulgaria and $2843 \mathrm{~km}^{2}$ in Greece). The Mesta/ Nestos River is the most important water resource in the region and has been the subject of bilateral negotiations for many years. For both countries it provides municipal water supply, irrigation and hydroelectric power production. 


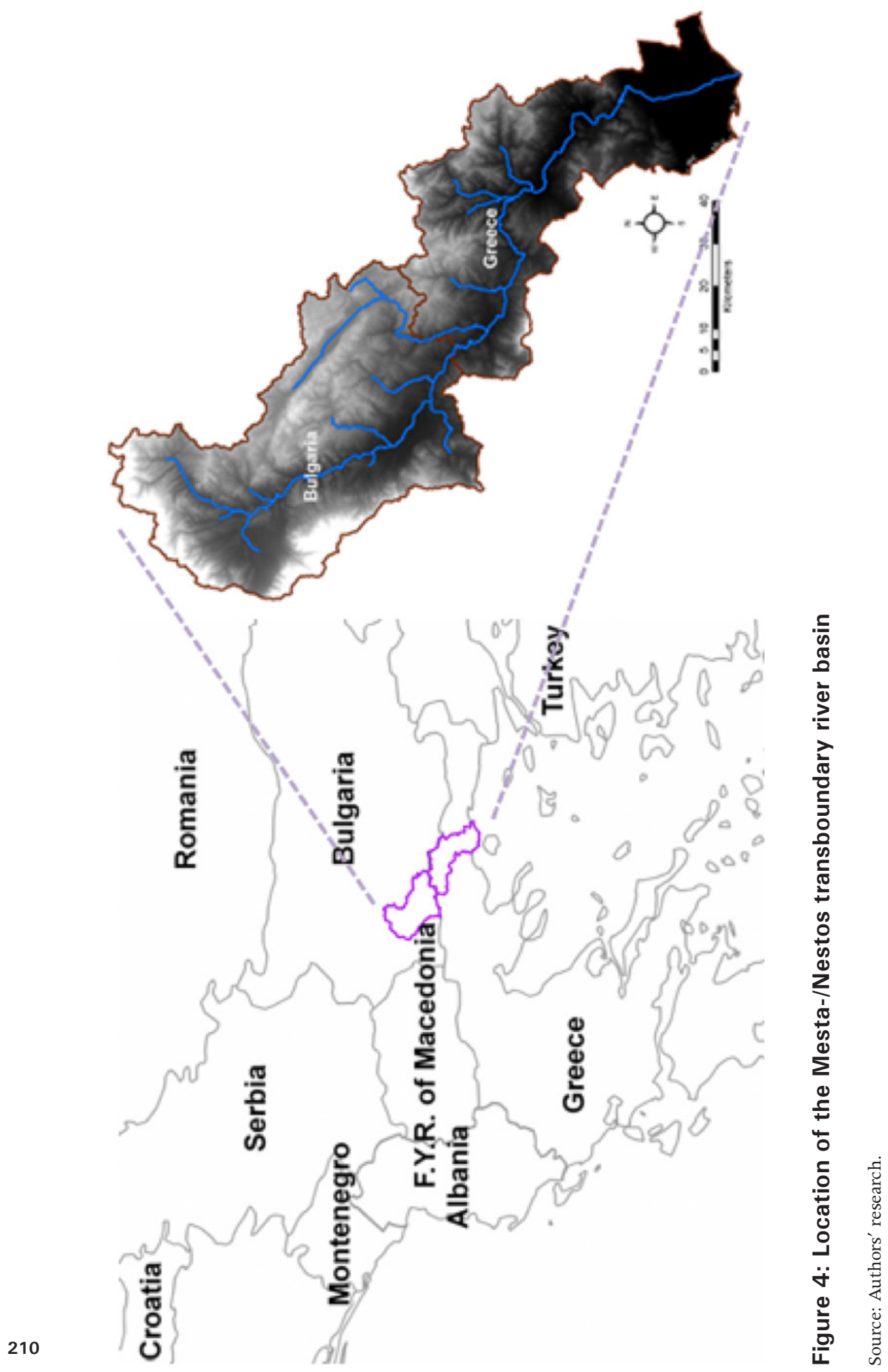


A conceptual model for TWRM in the Mesta/Nestos Basin is illustrated in Figure 5. This model employs the following seven steps and may be adapted to any case study of transboundary waters.

1. stakeholder consultation and collaboration, social issues, legal and institutional agreements: this step should interact with each following step

2. problem definition: transboundary diagnostic analysis (TDA)

3. agree on data collection, common monitoring and data sharing

4. develop a common vision and common strategic action plan (CSAP)

5. physical and environmental assessment and modelling

6. scenario analysis and decision support systems (DSS) and

7. transfer of models and DSS to stakeholders, applications.

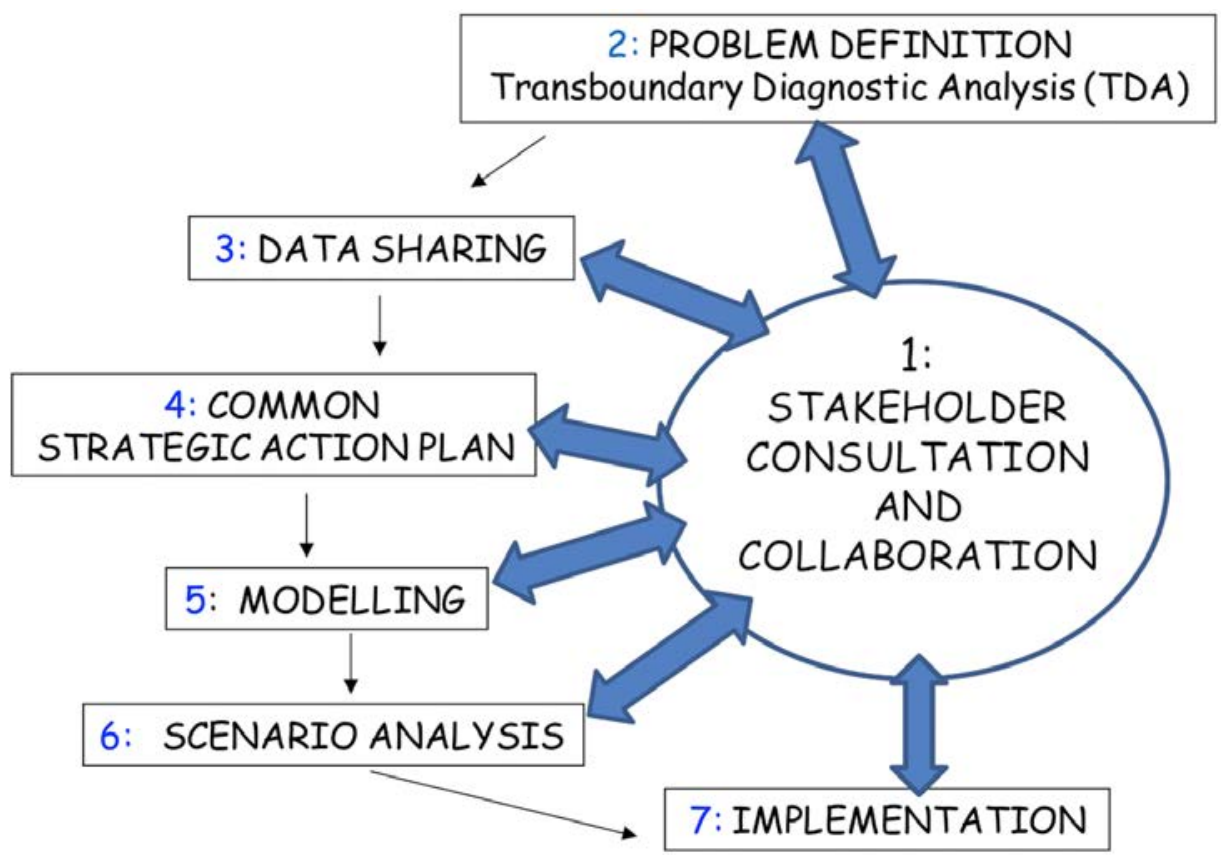

Figure 5: A conceptual model for effective management of transboundary water resources

Source: Authors' research.

In the Mesta/Nestos Basin, step 1 of the proposed model aiming to address the lack of communication between scientists, experts, water managers and public stakeholders was achieved with the organisation of a series of workshops and 
roundtables. TDA analysis (step 2) focused on improving the understanding of water resources in the project region and their environmental status, in order to identify issues of transboundary concern and their causes. The prepared TDA was the baseline for the interventions and priority actions that were specified in the CSAP. Step 3 targeted the development of common protocols on data collection, installation of monitoring sensors, in situ measurements in both countries and, last but not least, sharing of the available information between the two countries. CSAP prioritised water management issues and computer based models (step 5) were used for investigating the importance and impacts of these issues. The models coupled hydrological modelling, hydropower production tools, economic tools, and agricultural models with climate change scenarios (Skoulikaris et al. 2011). The simulation results set the base for the scenario analysis and the development of DSS with the use of multi-criteria decision analysis methods (step 6, see Ganoulis et al 2008). The final outputs (step 7) were communicated to water management authorities.

\section{Conclusions}

Ongoing social and political problems continue to pose a threat to stability in the Balkans. This atmosphere, in some cases, has hindered INWEB's ability to develop transparency and sharing, and it has sometimes been difficult to achieve full cooperation between stakeholders. There is no precedent for data sharing on an international basis in the Balkans, and hesitancy may be encountered when cooperation is proposed.

One of INWEB's greatest achievements, however, has been to establish the framework under which scientists can cooperate and work together on various joint projects. The fact that INWEB has facilitated the forging of personal links and trust is reflected in how individual scientists present cooperative projects to their respective national institutions. This result cannot be quantified, but it clearly cannot be disregarded. Overall, the work of the UNESCO Chair/ INWEB at the Aristotle University of Thessaloniki demonstrates that effective networking and information sharing are strategic instruments to promote peace and stability through transboundary water resources management.

Professor Jacques Ganoulis is Director of the UNESCO Chair/INWEB (International Network of Water/Environment Centres for the Balkans) at the Aristotle University of Thessaloniki, Greece.

Katie Quartano works with the UNESCO Chair/INWEB and has an international background in business administration and tourism.

Dr Charalampos Skoulikaris is Research Associate at the Balkan Environment

Centre and Secretary General of the UNESCO Chair/INWEB. 
35. Promoting cooperation for transboundary water security: The experience of the UNESCO Chair/INWEB

\section{References}

Ganoulis, J., 2006. 'Water resources management and environmental security in Mediterranean transboundary river basins', in B. Morel and I. Linkov (eds) Environmental Security and Environmental Management: The role of risk assessment, Springer, Heidelberg.

— 2007. 'Integrated management of transboundary aquifers in Southeastern Europe'. A report within GEF IW: LEARN Activity D2. GWP-Med, UNESCO Chair and Network INWEB, Thessaloniki.

—, 2009. Risk Analysis of Water Pollution, 2nd ed., WILEY-VCH, Weinheim.

—, Duckstein L., Literathy P. and Bogardi, I. (eds), 1996. Transboundary Water Resources Management: Institutional and engineering approaches, NATO ASI SERIES, Partnership Sub-Series 2: Environment, vol. 7, SpringerVerlag, Heidelberg.

—, Murphy, I.L. and Brilly M., (eds), 2000. Transboundary Water Resources in the Balkans: Initiating a sustainable co-operative network, NATO ASI SERIES, Partnership Sub-Series 2: Environmental Security, vol. 47, Kluwer Academic, Dordrecht, Boston, London.

—, Skoulikaris, H. and Monget, J.M., 2008. 'Involving stakeholders in transboundary water resources management: the Mesta/Nestos "HELP" basin', Water SA Journal 34(4):461-7.

- Aureli, A. and Fried, J. (eds.), 2011. Transboundary Water Resources Management: A multidisciplinary approach, WILEY-VCH, Weinheim.

Global Water Partnership (GWP), 2000. 'Integrated water resources management', Technical Committee Background Paper No 4, Stockholm, Sweden. Available at: http://www.gwptoolbox.org/images/stories/gwplibrary/background/tac_4_ english.pdf.

INWEB, 2008. Inventories of Transboundary Groundwater Aquifers in the Balkans, UNESCO Chair and Network INWEB, Thessaloniki, Greece. Available online at: http://www.inweb.gr/.

Skoulikaris Ch. and Ganoulis, J., 2011. 'Assessing climate change impacts at river basin scale by integrating lobal circulation models with regional hydrological simulations', European Water 34:53-60.

United Nations World Water Development Report (UN WWDR), 2006. Water: A shared responsibility, UNESCO Publishing, Paris. Available at: http://www. unesco.org/water/wwap/wwdr/. 
Global Water: Issues and Insights

—, 2009. Water in a Changing World, UNESCO Publishing, Paris. Available at: http://www.unesco.org/water/wwap/wwdr/.

UNESCO/ISARM, 2001. A Framework Document. Non Serial Documents in Hydrology, Paris.

World Bank, 1987. Water Resources Management in South Eastern Europe, vol. I, Issues and Directions. 
This text taken from Global Water: Issues and Insights by R. Quentin Grafton, Paul Wyrwoll, Chris White and David Allendes, published May 2014 by ANU Press, The Australian National University, Canberra, Australia. 